\title{
Tolerance of precocious dwarf cashew clones to salt stress during rootstock formation stage
}

\author{
Geovani S. de Lima ${ }^{1}$, Jailson B. da Silva ${ }^{1}$, Leandro de P. Souza ${ }^{2}$, Reginaldo G. Nobre ${ }^{3}$, \\ Lauriane A. dos A. Soares ${ }^{1} \&$ Hans R. Gheyi ${ }^{2}$
}

\begin{abstract}
${ }^{1}$ Universidade Federal de Campina Grande/Centro de Ciências e Tecnologia Agroalimentar/Unidade Acadêmica de Ciências Agrárias, Pombal, PB, Brasil E-mail: geovani.soares@pq.cnpq.br (Corresponding author) - ORCID: 0000-0001-9960-1858; jailson.batista2015@hotmail.com - ORCID: 0000-00030839-4799; lauriane.soares@pq.cnpq.br - ORCID: 0000-0002-7689-9628

${ }^{2}$ Universidade Federal de Campina Grande/Centro de Tecnologia e Recursos Naturais/Programa de Pós-Graduação em Engenharia Agrícola, Campina Grande, PB, Brasil. E-mail: engenheiropadua@hotmail.com - ORCID: 0000-0001-7588-2413; hans@pq.cnpq.br - ORCID: 0000-0002-1066-0315

${ }^{3}$ Universidade Federal Rural do Semi-Árido/Departamento de Ciência e Tecnologia, Caraúbas, RN, Brasil. E-mail: reginaldo.nobre@ufersa.edu.br ORCID: 0000-0002-6429-1527
\end{abstract}

\begin{abstract}
This study was conducted to evaluate the tolerance of precocious dwarf cashew clones to irrigation with waters of different salinity levels during rootstock formation. The experimental design consisted of randomized blocks, arranged in a $5 \times 3$ factorial scheme, corresponding to five levels of electrical conductivity of irrigation water $\left(0.4 ; 1.2 ; 2.0 ; 2.8\right.$ and $\left.3.6 \mathrm{dS} \mathrm{m}^{-1}\right)$ and three clones of precocious dwarf cashew (Faga 11, Embrapa 51, CCP 76), with three replicates. Water salinity above $0.4 \mathrm{dS} \mathrm{m}^{-1}$ inhibited chlorophyll synthesis and growth, but led to cashew seedlings with the Dickson Quality Index (DQI) higher than the acceptable limit. Based on the relative yield of the total dry mass, the clones Faga 11, Embrapa 51 and CCP 76, at the highest salinity level studied, were classified as moderately sensitive, sensitive and moderately tolerant, respectively. There was interaction between water salinity and precocious dwarf cashew clones for chlorophyll a content, chlorophyll b content and DQI at 75 days after sowing.
\end{abstract}

Key words: Anacardium occidentale L., water scarcity, saline water

\section{Tolerância de clones de cajueiro anão-precoce ao estresse salino na fase de formação de porta-enxerto}

RESUMO: Conduziu-se esta pesquisa com o propósito de avaliar a tolerância de clones de cajueiro anãoprecoce à irrigação com águas de diferentes níveis de salinidade durante a formação dos porta-enxertos. Utilizou-se delineamento de blocos casualizados, arranjados em esquema fatorial de $5 \times 3$, correspondendo a cinco níveis de condutividade elétrica da água de irrigação $\left(0,4 ; 1,2 ; 2,0 ; 2,8\right.$ e $\left.3,6 \mathrm{dS} \mathrm{m}^{-1}\right)$ e três clones de cajueiro anão-precoce (Faga 11, Embrapa 51, CCP 76), com três repetições. Salinidade da água superior a $0,4 \mathrm{dS} \mathrm{m}^{-1}$ inibiu a síntese de clorofila e o crescimento, contudo, obteve-se mudas de cajueiro com o Indice de Qualidade de Dickson (IQD) superior ao limite aceitável. Com base no rendimento relativo da fitomassa seca total, os clones Faga 11, Embrapa 51 e CCP 76, no nível mais elevado de salinidade estudado foram classificados como moderadamente sensível, sensível e moderadamente tolerante, respectivamente. Houve interação significativa entre os níveis salinos da água e os clones de cajueiro anão-precoce para os teores de clorofila a, b e o IQD, aos 75 dias após o semeio.

Palavras-chave: Anacardium occidentale L., escassez hídrica, água salina 


\section{INTRODUCTION}

Cashew (Anacardium occidentale L.) is a species widely cultivated in the semiarid region of northeastern Brazil, standing out as an important option in the generation of employment and income. It has a planted area of approximately 616,189 ha, and produces about $98.7 \%$ of the national production, and its main producers are the states of Ceará $(42,597$ t), Rio Grande do Norte (33,912 t) and Piauí (28,292 t) (Araújo et al., 2014; Suassuna et al., 2016).

Most cashew orchards in Brazil are located in the northeastern semiarid region, where water is scarce because the low levels of rainfall and high rates of evapotranspiration contribute decisively to reducing this resource. Combined with this climatic conditioning, the predominance of water with high salt concentrations is common in this region (Dalchiavon et al., 2016).

Although the use of saline water stands out as an alternative for the expansion and safety of irrigated agriculture in the semiarid region, excess salts may result in inhibition of plant growth, for reducing the osmotic potential of the soil solution, restricting the availability of water and/or due to excessive accumulation of ions in plant tissues, which may cause ionic toxicity and/or imbalance in nutrient absorption (Araújo et al., 2014). However, the response of plants to salt stress depends on the species and/or clone, on the stage of development of the same genotype, on the intensity and duration of stress and on edaphoclimatic conditions (Munns \& Tester, 2008).

The variability in the level of tolerance among species and/ or clones is related to the capacity for osmotic adjustment, synthesis of compatible osmolytes and activation of enzymatic antioxidant systems, which increase the tolerance capacity of plants grown under conditions of high salt concentrations, which facilitate the absorption and retention of water, protect the functions of chloroplasts and maintain ionic homeostasis (Freitas et al., 2014).

Given the importance of cashew for the semiarid region of Northeastern Brazil, identifying salt-tolerant clones becomes an important attractive factor for the expansion of this fruit crop in the region. In view of the above, the objective of this study was to evaluate the tolerance of precocious dwarf cashew clones to water salinity during the rootstock formation stage.

\section{Material and Methods}

The experiment was conducted using $1.25 \mathrm{dm}^{3}$ plastic containers under greenhouse conditions, at the Center of Sciences and Agrifood Technology of the Federal University of Campina Grande (CCTA/UFCG), located in the municipality of Pombal, PB, Brazil, at the local geographic coordinates $6^{\circ} 48^{\prime} 16^{\prime \prime} \mathrm{S}, 37^{\circ} 49^{\prime} 15^{\prime \prime} \mathrm{W}$ and mean altitude of $175 \mathrm{~m}$.

The treatments resulted from the combination of five levels of electrical conductivity of irrigation water - ECw (0.4; $1.2 ; 2.0 ; 2.8$ and $3.6 \mathrm{dS} \mathrm{m}^{-1}$ ) associated with three clones of precocious dwarf cashew (Faga 11, Embrapa 51, CCP 76). The experimental design was in randomized blocks in a $5 \times 3$ factorial arrangement, with three replicates and two plants per plot. The levels of water salinity were based on a study previously conducted by Sousa et al. (2011).

Irrigation waters with the respective levels of electrical conductivity $\left(0.4 ; 1.2 ; 2.0 ; 2.8\right.$ and $\left.3.6 \mathrm{dS} \mathrm{m}^{-1}\right)$ were prepared by dissolving $\mathrm{NaCl}$ in public-supply water $\left(\mathrm{ECw}=0.30 \mathrm{dS} \mathrm{m}^{-1}\right)$ from the municipality of Pombal, $\mathrm{PB}$, based on the relationship between ECw and salt concentration $\left(\mathrm{mmol}_{\mathrm{c}} \mathrm{L}^{-1}=10 \mathrm{x} \mathrm{ECw}\right.$, in $\mathrm{dS} \mathrm{m}^{-1}$ ) according to Richards (1954).

The containers were filled using a 2:1:1 ratio of sandy loam Entisol, sand and organic matter (well-decomposed bovine manure was used as a source), from the rural area of São Domingos, $\mathrm{PB}$, whose chemical and physical characteristics were obtained according to the methodologies proposed by Teixeira et al. (2017): $\mathrm{Ca}^{2+}=2.42 \mathrm{cmol} \mathrm{kg}_{\mathrm{c}} \mathrm{kg}^{-1} \mathrm{Mg}^{2+}=5.84 \mathrm{cmol} \mathrm{kg}^{-1}$; $\mathrm{Na}^{+}=0.09 \mathrm{cmol}_{\mathrm{c}} \mathrm{kg}^{-1} ; \mathrm{K}^{+}=0.21 \mathrm{cmol}_{\mathrm{c}} \mathrm{kg}^{-1} ; \mathrm{H}^{+}+\mathrm{Al}^{3+}=0 \mathrm{cmol}_{\mathrm{c}} \mathrm{kg}^{-1}$; $\mathrm{CEC}=8.56 \mathrm{cmol}_{\mathrm{c}} \mathrm{kg}^{-1} ;$ organic matter $=3.80 \mathrm{dag} \mathrm{kg}^{-1} ; \mathrm{P}=11.99$ $\mathrm{mg} \mathrm{kg}^{-1} ; \mathrm{pH}$ in water $(1: 2.5)=7.00$; electrical conductivity of soil saturation extract $=0.20 \mathrm{dS} \mathrm{m}^{-1}$; sand $=846.3 \mathrm{~g} \mathrm{~kg}^{-1}$; silt $=137.0$ $\mathrm{g} \mathrm{kg}^{-1}$; clay $=16.3 \mathrm{~g} \mathrm{~kg}^{-1}$; moisture at $33.42 \mathrm{kPa}=11.16 \mathrm{dag} \mathrm{kg}^{-1}$; moisture at $1519.5 \mathrm{kPa}=4.23 \mathrm{dag} \mathrm{\textrm {kg } ^ { - 1 }}$.

Prior to sowing, the soil moisture content was raised to field capacity, using the respective water of each treatment. After transplanting, irrigation was performed daily by applying in each container a volume of water to keep soil moisture close to field capacity, and the applied volume was determined according to the water requirement of the plants, estimated by water balance, according to Eq.1.

$$
\mathrm{VC}=\frac{\mathrm{VA}-\mathrm{VD}}{1-\mathrm{LF}}
$$

where:

VC - volume consumed, considering the water volume applied to the plants (VA) on the previous day;

VD - volume drained, quantified in the morning of the next day; and,

LF - desired leaching fraction, fixed at 0.10, aimed at reducing the accumulation of salts in the root zone.

Sowing was performed at $3 \mathrm{~cm}$ depth, by placing one seed per container in the vertical position, with the base facing up (point of attachment of the nut to the peduncle), as recommended by EMBRAPA- CNPAT.

Phosphorus and nitrogen fertilization was carried out as recommended by Novais et al. (1991), applying the equivalent to $300 \mathrm{mg}$ of $\mathrm{P}_{2} \mathrm{O}_{5}$ and $100 \mathrm{mg}$ of $\mathrm{N} \mathrm{kg}^{-1}$ of soil, respectively. Monoammonium phosphate and urea were used as sources of phosphorus and nitrogen, which were applied weekly. The requirement of micronutrients of cashew plant was met through fortnightly applications of a Ubyfol solution [(N (15\%); $\mathrm{P}_{2} \mathrm{O}_{5}(15 \%) ; \mathrm{K}_{2} \mathrm{O}$ (15\%); $\mathrm{Ca}(1 \%) ; \mathrm{Mg}(1.4 \%) ; \mathrm{S}(2.7 \%)$; $\mathrm{Zn}(0.5 \%) ; \mathrm{B}(0.05 \%) ; \mathrm{Fe}(0.5 \%) ; \mathrm{Mn}(0.05 \%) ; \mathrm{Cu}(0.5 \%)$; Mo (0.02\%)] containing $1.0 \mathrm{~g} \mathrm{~L}^{-1}$. The sprays were performed on the adaxial and abaxial sides of the leaves.

The effects of treatments on the crop were evaluated at 50 and 75 days after sowing (DAS). Plant height (PH), stem diameter (SD) and leaf area (LA) were determined at 50 and 
75 DAS. The relative growth rates of stem diameter $\left(\mathrm{RGR}_{\mathrm{SD}}\right)$, plant height $\left(\mathrm{RGR}_{\mathrm{PH}}\right)$ and leaf area were evaluated according to Benincasa (2003). The following parameters were measured only at 75 DAS: chlorophyll a (Chl a), b ( $\mathrm{Chl} \mathrm{b})$, carotenoid (Car), net assimilation rate (NAR), total dry mass (TDM), leaf succulence (SUC) and Dickson quality index - DQI (Dickson et al., 1960). Leaf area was determined through a non-destructive method, by measuring the length and width of the leaves $(\mathrm{cm})$ considering only those with a minimum length of $1.5 \mathrm{~cm}$ and with at least $50 \%$ of their photosynthetically active area according to the methodology (Eq. 2) proposed by Carneiro et al. (2007).

$$
\mathrm{LA}=(\mathrm{L} \mathrm{W}) \mathrm{F}
$$

where:

$$
\begin{array}{ll}
\text { LA } & \text { - leaf area; } \\
\text { L } & \text { - length; } \\
\text { W } & \text { - width of each leaf; and, } \\
\text { F } & \text { - factor }=0.6544 .
\end{array}
$$

Chlorophyll a and b contents were determined according to Arnon (1949), using samples of 5 discs of the blade of the third mature leaf from the apex. From the extracts, the concentrations of chlorophyll and carotenoids were determined in the solutions by a spectrophotometer at absorbance wavelengths (ABS) $(470,646$, and $663 \mathrm{~nm})$, according to Eqs. 3 and 4 .

$$
\begin{aligned}
& \text { Chlorophyll a }(\mathrm{Chl} \mathrm{a})=12.21 \mathrm{ABS}_{663}-2.81 \mathrm{ABS}_{646} \\
& \text { Chlorophyll b }(\mathrm{Chl} \mathrm{b})=20.13 \mathrm{~A}_{646}-5.03 \mathrm{ABS}_{663}
\end{aligned}
$$

Total carotenoids $(\mathrm{Car})=\frac{\left(1000 \mathrm{ABS}_{470}-1.82 \mathrm{Chl} \mathrm{a}-85.02 \mathrm{Chl} \mathrm{b}\right)}{198}$

Chlorophyll $\mathrm{a}$ and $\mathrm{b}$ and carotenoid contents were expressed in $\mathrm{mg} \mathrm{g}^{-1} \mathrm{FM}$ (fresh matter).

To quantify the total dry mass of the plants (stem, leaf and roots), the stem of each plant was cut close to the soil and then dried in a forced air ventilation oven, at $65^{\circ} \mathrm{C}$, until constant weight.

NAR $\left(\mathrm{g} \mathrm{m}^{-2} \mathrm{~d}^{-1}\right)$ was determined in the periods between two evaluations (50 and 75 DAS) through Eq. (6).

$$
\operatorname{NAR}\left[\frac{\left(\mathrm{P}_{2}-\mathrm{P}_{1}\right)}{\left(\mathrm{t}_{2}-\mathrm{t}_{1}\right)}\right]\left[\frac{\left(\log \mathrm{LA}_{2}-\log \mathrm{LA}_{1}\right)}{\left(\mathrm{LA}_{2}-\mathrm{LA}_{1}\right)}\right]
$$

where: and,

$\mathrm{P}_{2}-\mathrm{P}_{1}$ - difference of dry mass $(\mathrm{g})$ between two evaluations,

$t_{2}-t_{1}-$ time interval between the two periods evaluated.

Leaf succulence - SUC $\left(\mathrm{g} \mathrm{cm}^{-2}\right)$ was determined according to the relationship proposed by Mantovani (1999), obtained through Eq. 7:

$$
\mathrm{SUC}=\frac{\mathrm{LFM}-\mathrm{LDM}}{\mathrm{LA}}
$$

where:

SUC - leaf succulence;

LFM - leaf fresh mass ( $\mathrm{g})$;

LDM - leaf dry mass (g); and,

LA - Leaf area $\left(\mathrm{cm}^{2}\right)$.

The quality of seedlings of the clones was determined by the Dickson quality index - DQI (Dickson et al., 1960), according to Eq. 8:

$$
\mathrm{DQI}=\frac{\mathrm{TDM}}{\left(\frac{\mathrm{PH}}{\mathrm{SD}}\right)+\left(\frac{\mathrm{SDM}}{\mathrm{RDM}}\right)}
$$

where:

DQI - Dickson quality index,

TDM - total dry mass, g;

$\mathrm{PH}$ - plant height, $\mathrm{cm}$;

SD - stem diameter, $\mathrm{mm}$;

SDM - shoot dry mass, g; and,

$\mathrm{RDM}$ - root dry mass, $\mathrm{g}$.

After verifying the homogeneity of variances, the obtained data were subjected to analysis of variance by the F test at 0.05 and 0.01 probability levels and, in case of significance, linear and quadratic polynomial regression analysis was performed for the water salinity levels, while means comparison test (Tukey) was carried out for clones. When the interaction between the factors (SL x CL) was significant, the salinity levels were further analyzed considering each clone, using the statistical software Sisvar (Ferreira, 2014).

\section{Results AND Discussion}

There was a significant effect of water salinity levels (Table 1) $(\mathrm{p}<0.01)$ on the contents of chlorophyll a $(\mathrm{Chl} \mathrm{a})$, chlorophyll b ( Chl b) and carotenoids (Car), relative growth rates of stem diameter $\left(\mathrm{RGR}_{\mathrm{SD}}\right)$, plant height $\left(\mathrm{RGR}_{\mathrm{PH}}\right)$ and leaf area $\left(R_{G R}\right)$ of precocious dwarf cashew plants. Regarding the clone factor and the interaction between factors (SL x CL), there were significant effects $(\mathrm{p}<0.05)$ only on chlorophyll a and $\mathrm{b}$ contents (Table 1 ).

The interaction between salinity levels and clones negatively influenced the chlorophyll a of precocious dwarf cashew and, according to the regression analysis (Figure 1A), there was a linear reduction with the increase in irrigation water salinity, regardless of the clone studied. Reductions of 15.49, 13.30 and $17.14 \%$ with per unit increase in ECw were found in the Chl a contents of the clones Faga 11, Embrapa 51 and CCP 76, respectively. In relative terms, there were reductions of 4.16 , 3.01 and $5.32 \mathrm{mg} \mathrm{g}^{-1} \mathrm{FM}$ in the $\mathrm{Chl}$ a contents of the clones Faga 11, Embrapa 51 and CCP 76 when subjected to ECW of $3.6 \mathrm{dS} \mathrm{m} \mathrm{m}^{-1}$, compared to plants cultivated with the lowest level of water salinity $\left(0.4 \mathrm{dS} \mathrm{m}^{-1}\right)$. Among the cashew clones studied, Faga 11 showed the lowest reduction in chlorophyll a 
Table 1. Summary of the analysis of variance for the contents of chlorophyll a (Chl a), chlorophyll b (Chl b) and carotenoids (Car) at 75 days after sowing (DAS) and relative growth rates of stem diameter $\left(\mathrm{RGR}_{\mathrm{SD}}\right)$, plant height $\left(\mathrm{RGR}_{\mathrm{PH}}\right)$ and leaf area $\left(\mathrm{RGR}_{\mathrm{LA}}\right)$ of precocious dwarf cashew clones irrigated with saline water, in the period from 50 to 75 DAS

\begin{tabular}{|c|c|c|c|c|c|c|}
\hline \multirow{2}{*}{ Source of variation } & \multicolumn{6}{|c|}{ Mean squares } \\
\hline & Chl a & Chl b & Car & $\mathrm{RGR}_{\mathrm{SD}}$ & RGRPH $_{\text {PH }}$ & $\mathbf{R G R}_{\mathrm{LA}}$ \\
\hline Saline levels (SL) & $23.17^{\star \star}$ & $28.31^{\star \star}$ & $8.09^{\star \star}$ & $0.000077^{\star \star}$ & $0.000040^{\star \star}$ & $0.000071^{\star \star}$ \\
\hline Linear regression & $83.39^{\star *}$ & $98.11^{\star *}$ & $29.53^{* *}$ & $0.000253^{\star *}$ & $0.000153^{\star *}$ & $0.000246^{\star \star}$ \\
\hline Quadratic regression & $5.94^{*}$ & $13.60^{* *}$ & $1.37^{\mathrm{ns}}$ & $0.000038^{\star *}$ & $0.0000001^{\text {ns }}$ & $0.000034^{\star \star}$ \\
\hline Clones (CL) & $5.25^{\star}$ & $9.88^{\star *}$ & $1.75^{\mathrm{ns}}$ & $0.000000960^{\text {ns }}$ & $0.000007^{\text {ns }}$ & $0.000000462^{\text {ns }}$ \\
\hline Interaction (SL x CL) & $3.45^{*}$ & $2.99^{*}$ & $0.41^{\mathrm{ns}}$ & $0.000000773^{\text {ns }}$ & $0.000005^{\text {ns }}$ & $0.000003^{\text {ns }}$ \\
\hline Blocks & $0.81^{\mathrm{ns}}$ & $0.23^{\text {ns }}$ & $0.17^{\mathrm{ns}}$ & $0.000001^{\text {ns }}$ & $0.000000523^{\text {ns }}$ & $0.000000793^{\text {ns }}$ \\
\hline Residual & 1.44 & 0.60 & 0.85 & 0.000000502 & 0.000004 & 0.000001 \\
\hline CV (\%) & 20.80 & 13.27 & 11.79 & 24.52 & 16.30 & 18.61 \\
\hline
\end{tabular}

ns, ${ }^{*},{ }^{* *}$ - Not significant, significant at $\mathrm{p} \leq 0.05$ and $\mathrm{p} \leq 0.01$, respectively; CV - Coefficient of variation

contents, a result that is considered important, as chlorophyll biosynthesis is closely related to nitrogen content in the plant.
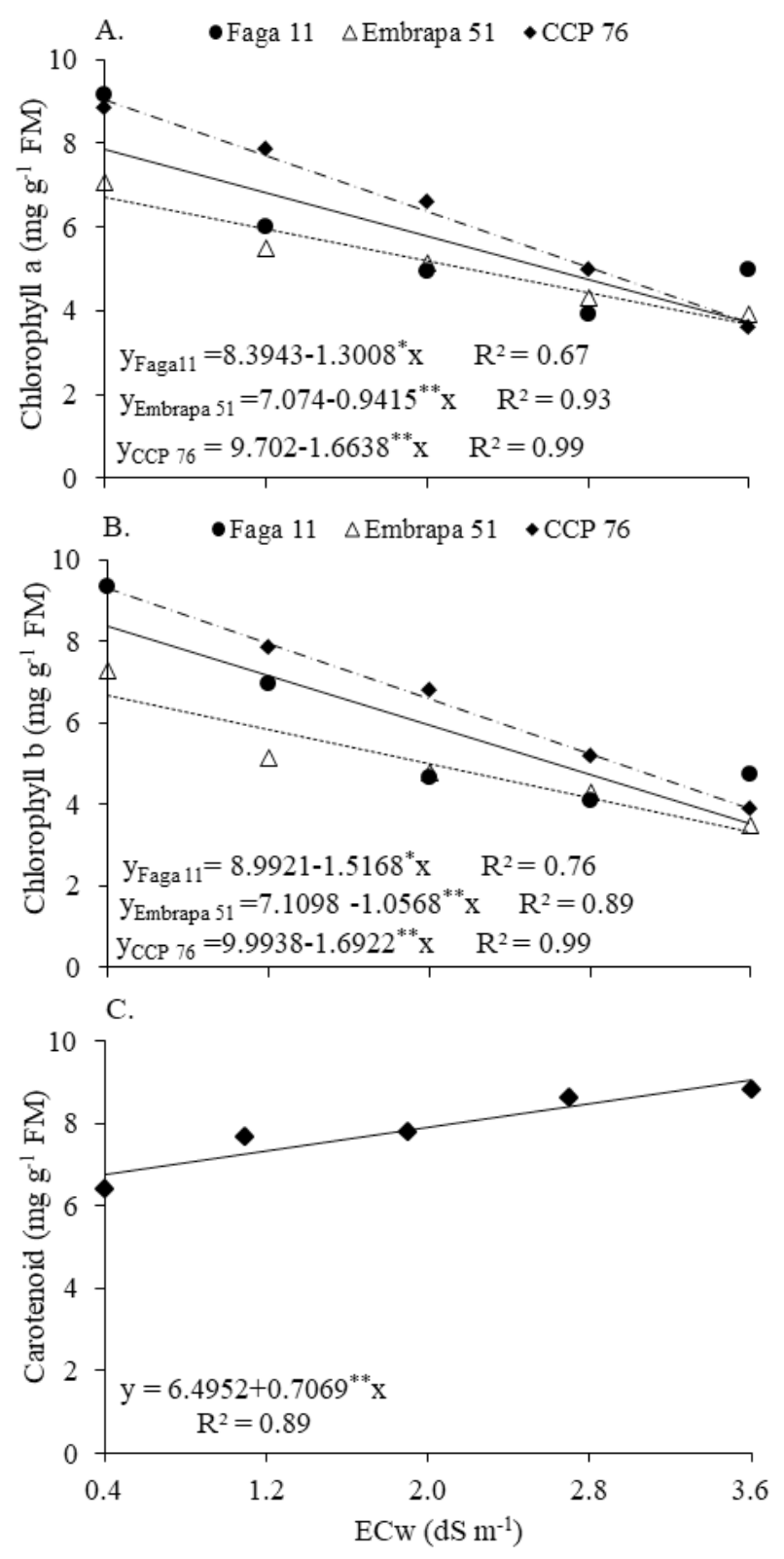

*, ** - Significant at $\mathrm{p} \leq 0.05$ and $\mathrm{p} \leq 0.01$ by $\mathrm{F}$ test, respectively

Figure 1. Chlorophyll a (A) and chlorophyll b (B) contents as a function of the interaction between the irrigation water salinity (ECw) and clones of precocious dwarf cashew, and carotenoid contents $(\mathrm{C})$ of precocious dwarf cashew irrigated with saline water, at 75 days after sowing
According to Freire et al. (2013), the reduction in the biosynthesis of photosynthesizing pigments in plants possibly occurs because the stress leads to increment in the enzymatic activity of chlorophyllase, which degrades the molecules of photosynthesizing pigments and induces structural destruction of chloroplasts, besides causing changes in the activity of pigment proteins. Lima et al. (2018), in a study with 'BRS 366 Jaburu' West Indian cherry irrigated with saline water (ECw from 0.8 and $3.8 \mathrm{dS} \mathrm{m}^{-1}$ ) under greenhouse conditions, concluded that chlorophyll a synthesis was significantly reduced with the use of saline water.

The chlorophyll b contents of cashew were also significantly affected by the interaction between water salinity levels and clones. According to the regression equations (Figure 1B), there were reductions of $16.86,14.86$ and $16.92 \%$ with per unit increase in ECw in Chl b contents of the clones Faga 11, Embrapa 51 and CCP 76, respectively, i.e., plants under irrigation with ECw of $3.6 \mathrm{dS} \mathrm{m} \mathrm{m}^{-1}$ had reductions in Chl b synthesis of 4.85, 3.38 and $5.41 \mathrm{mg} \mathrm{g}^{-1} \mathrm{FM}$, respectively, compared to those under water salinity of $0.4 \mathrm{dS} \mathrm{m}^{-1}$. The excess of salts in water and/or soil causes imbalances in the chloroplast activities (decrease in the synthesis of 5-aminolevulinate acid, a precursor molecule of chlorophyll), inducing an increase in enzymatic activity, which results in degradation of the molecules of photosynthesizing pigments, such as chlorophyll b (Cavalcante et al., 2011). Silva et al. (2017), studying the effects of irrigation water salinity (ECw: 0.3 to $3.5 \mathrm{dS} \mathrm{m}^{-1}$ ) on the contents of photosynthetic pigments and leaf morphophysiology of guava seedlings $\mathrm{cv}$. 'Paluma', concluded that chlorophyll b contents in the leaves were inhibited by the increase in irrigation water salinity.

The synthesis of carotenoids increased linearly with the use of saline water in irrigation and, based on the regression equation (Figure 1C), there were increments of $10.88 \%$ per unit increase in the electrical conductivity of water, that is, cashew plants when grown with $3.6 \mathrm{dS} \mathrm{m}^{-1}$ water had an increase in their carotenoid contents of $33.37 \%\left(2.26 \mathrm{mg} \mathrm{g}^{-1} \mathrm{FM}\right)$ compared to those subjected to the lowest ECw level $\left(0.4 \mathrm{dS} \mathrm{m}^{-1}\right)$. The increment in carotenoid biosynthesis occurs as a strategy to minimize the damage to the photosynthetic apparatus, due to the stress imposed, standing out as a way of dissipating the excess of light energy, used by plants, especially under the stress conditions caused by salinity, in which carotenoids play a photoprotective role. In addition, they can act as antioxidant agents, protecting membrane lipids from oxidative stress (Falk \& Munné-Bosch, 2010). Increase in carotenoid synthesis was 
also observed by Lima et al. (2018) in West Indian cherry plants cultivated with saline waters.

As for plant growth, the relative growth rate in stem diameter of cashew plants was sharply reduced by irrigation water salinity in the period from 50 to 75 days after sowing. According to the regression equation (Figure 2A), the highest $\mathrm{RGR}_{\mathrm{SD}}\left(0.007892 \mathrm{~mm} \mathrm{~mm}^{-1} \mathrm{~d}^{-1}\right)$ was obtained under the lowest water salinity level $\left(0.4 \mathrm{dS} \mathrm{m}^{-1}\right)$, decreasing from this point on, with the lowest value in plants that were under irrigation with $3.6 \mathrm{dS} \mathrm{m}^{-1}$ water $\left(0.0001080 \mathrm{~mm}^{-1} \mathrm{~d}^{-1}\right)$. Comparatively, plants under ECw of $3.6 \mathrm{dS} \mathrm{m}^{-1}$ had a reduction of $0.007784 \mathrm{~mm} \mathrm{~d}^{-1}$ in comparison to those irrigated with $0.4 \mathrm{dS} \mathrm{m} \mathrm{m}^{-1}$ water. The reduction in the relative growth in stem diameter is partly due to the decrease in osmotic potential in the root zone, caused by excess soluble salts, which leads to a reduction in turgor and results in decreased cell expansion, reducing the growth rate of plants (Khalid \& Silva, 2010). Carneiro et al. (2007), in a study
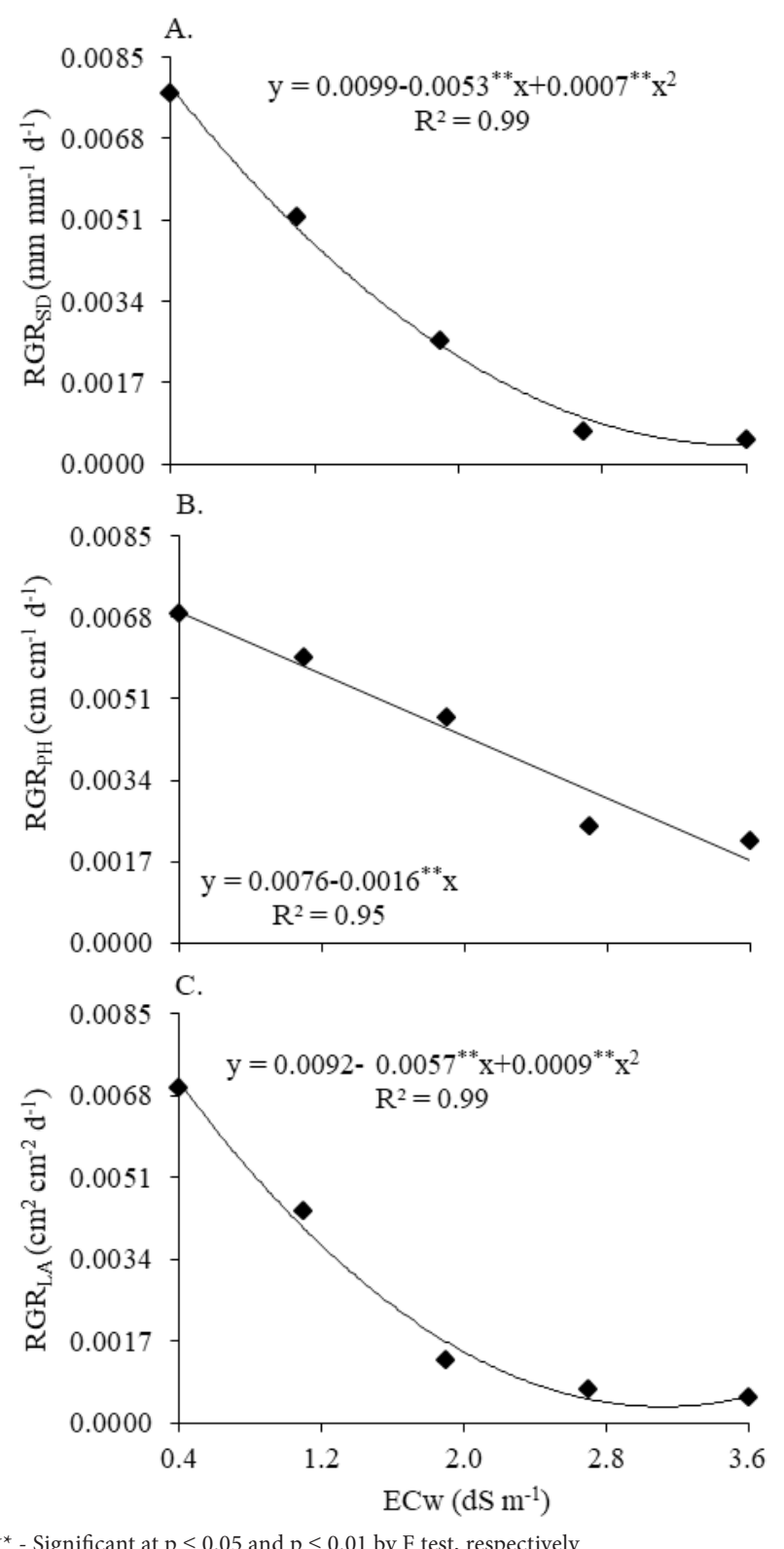

*, ** - Significant at $\mathrm{p} \leq 0.05$ and $\mathrm{p} \leq 0.01$ by $\mathrm{F}$ test, respectively

Figure 2. Relative growth rates of stem diameter $\left(R_{G R}-A\right)$, plant height $\left(\mathrm{RGR}_{\mathrm{PH}}-\mathrm{B}\right)$ and leaf area $\left(\mathrm{RGR}_{\mathrm{LA}}-\mathrm{C}\right)$ of precocious dwarf cashew clones irrigated with saline water $(\mathrm{ECw})$, in the period from 50 to 75 days after sowing evaluating the sensitivity of the CCP76 clone of precocious dwarf cashew to salt stress (ECw: 0.8 to $4.0 \mathrm{dS} \mathrm{m}^{-1}$ ), also found that the increase in irrigation water salinity inhibited the growth in stem diameter, which decreased by $5.23 \%$ per unit increase in ECw.

The relative growth rate in height of cashew plants decreased linearly as the water salinity levels increased, with a reduction of $21.05 \%$ per unit increment in $\mathrm{ECw}$ (Figure $2 \mathrm{~B}$ ). There was a reduction of $73.56 \%\left(0.00512 \mathrm{~cm} \mathrm{~cm}^{-1} \mathrm{~d}^{-1}\right)$ in the $\mathrm{RGR}_{\mathrm{PH}}$ of plants irrigated with $3.6 \mathrm{dS} \mathrm{m}^{-1}$ water compared to those that received the lowest salinity level $\left(0.4 \mathrm{dS} \mathrm{m}^{-1}\right)$. As with $\mathrm{RGR}_{\mathrm{SD}}$, the decrease in $\mathrm{RGR}_{\mathrm{PH}}$ is a consequence of the high concentration of salts in the water, as it directly influences the osmotic potential and consequently the total water potential, besides the action of ions on the protoplasm, especially $\mathrm{Na}^{+}$and $\mathrm{Cl}^{-}$, which alters the ionic homeostasis. In addition, water is osmotically retained in a saline solution (due to the decrease in its free energy) so that the increase in salt concentration makes water less and less available to plants, consequently inhibiting their growth (Diniz et al., 2013). In a study evaluating the effects of irrigation with saline waters (ECw ranging from 0.3 to $3.1 \mathrm{dS} \mathrm{m}^{-1}$ ) on the morphophysiology of precocious dwarf cashew, Souza et al. (2018) found that the growth in plant height was reduced by $18.04 \%$ when plants were cultivated with $\mathrm{ECw}$ of $3.1 \mathrm{dS} \mathrm{m}^{-1}$, compared to those under the lowest level of salinity $\left(0.3 \mathrm{dS} \mathrm{m}^{-1}\right)$.

The relative growth rate in leaf area of cashew clones was also negatively affected by the increase in water salinity levels. The regression equation (Figure 2C) shows that the best fit to the data was obtained with the quadratic model, with the maximum value of $\mathrm{RGR}_{\mathrm{LA}}\left(0.00706 \mathrm{~cm}^{2} \mathrm{~cm}^{-2} \mathrm{~d}^{-1}\right)$ in plants

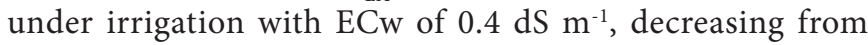
this level and reaching the $\mathrm{RGR}_{\mathrm{LA}}$ of $0.00017 \mathrm{~cm}^{2} \mathrm{~cm}^{-2} \mathrm{~d}^{-1}$ under the highest water salinity $\left(3.2 \mathrm{dS} \mathrm{m}^{-1}\right)$. Under salt stress conditions, plants reduce their leaf area as an acclimatization strategy because, due to the concentrations of salts present in water and/or soil, there is greater energy expenditure for the absorption of water and nutrients, so in order to minimize cellular water deficit, plants reduce their leaf area as a response to stress, thereby reducing water losses by transpiration to the environment (Gomes et al., 2011). Bezerra et al. (2017), when studying the effects of irrigation water salinity (ECw from 0.5 to $5.5 \mathrm{dS} \mathrm{m}^{-1}$ ) on the growth of two clones of precocious dwarf cashew (CCP06 and CCP1001), observed that leaf area growth was linearly inhibited, with relative reductions of 4.92 and $4.18 \%$ per unit increase in ECw, respectively.

The summary of the analysis of variance (Table 2) shows that the total dry mass (TDM), net assimilation rate (NAR), leaf succulence (SUC) and Dickson Quality Index (DQI) of seedlings of precocious dwarf cashew clones were significantly influenced $(\mathrm{p}<0.01)$ by irrigation with saline waters. The clone factor and the interaction between factors (SL $x \mathrm{CL}$ ) caused a significant effect on SUC $(\mathrm{p}<0.01)$ and DQI $(\mathrm{p}<0.05)$.

The increase in water salinity caused a reduction in the net assimilation rate of precocious dwarf cashew plants and, according to the regression equation (Figure $3 \mathrm{~A}$ ), the highest NAR $\left(0.000285 \mathrm{~g} \mathrm{~cm}^{-2} \mathrm{~d}^{-1}\right)$ was found in plants irrigated with $\mathrm{ECw}$ of $0.4 \mathrm{dS} \mathrm{m}^{-1}$, with reduction in this variable as 
Table 2. Summary of the analysis of variance of net assimilation rate (NAR), total dry mass (TDM), leaf succulence (SUC) and Dickson Quality Index (DQI) of precocious dwarf cashew clones irrigated with saline water, at 75 days after sowing

\begin{tabular}{|c|c|c|c|c|}
\hline \multirow{2}{*}{ Source of variation } & \multicolumn{4}{|c|}{ Mean squares } \\
\hline & NAR & TDM & SUC & DQI \\
\hline Saline levels (SL) & $0.0000000354^{* *}$ & $13.14^{\star \star}$ & $0.020^{\star \star}$ & $2.814^{\star \star}$ \\
\hline Linear regression & $0.0000001^{\star \star}$ & $49.59^{* x}$ & $0.069^{\star \star}$ & $10.443^{\star \star}$ \\
\hline Quadratic regression & $0.00000001^{\star}$ & $2.09^{\text {ns }}$ & $0.011^{\star}$ & $0.254^{*}$ \\
\hline Clones (CL) & $0.00000000150^{\text {ss }}$ & $3.12^{\text {ns }}$ & $0.016^{* *}$ & $0.408^{*}$ \\
\hline Interaction (SL x CL) & $0.00000000226^{1 \mathrm{~s}}$ & $1.77^{\mathrm{ns}}$ & $0.009^{* *}$ & $0.236^{*}$ \\
\hline Blocks & $0.00000000130^{\text {ss }}$ & $1.21^{\mathrm{ns}}$ & $0.0006^{\text {ns }}$ & $0.120^{\text {ns }}$ \\
\hline Residual & 0.000000000990 & 1.26 & 0.0009 & 0.063 \\
\hline CV (\%) & 16.34 & 24.58 & 14.28 & 18.44 \\
\hline
\end{tabular}
of variation

water salinity levels increased, whose minimum value was $0.000157 \mathrm{~g} \mathrm{~cm}^{-2} \mathrm{~d}^{-1}$, obtained in plants under ECw of $3.6 \mathrm{dS} \mathrm{m}^{-1}$. When comparing the NAR of plants under irrigation with ECW of $3.6 \mathrm{dS} \mathrm{m} \mathrm{m}^{-1}$ to that of plants under the lowest salinity level $\left(0.4 \mathrm{dS} \mathrm{m}^{-1}\right)$, there was a reduction of $0.000128 \mathrm{~g} \mathrm{~cm}^{-2} \mathrm{~d}^{-1}$. The reduction of growth in terms of leaf area (Figure $2 \mathrm{C}$ ) resulted in a decrease in the available surface for light interception and, consequently, caused a decrease in photosynthetic capacity and biomass allocation by cashew plants, which directly influenced the net assimilation rate of the plants. Sousa Júnior et al. (2012), in a study evaluating salinity tolerance ( 0 and $100 \mathrm{~mol} \mathrm{~m}^{-3}$ of $\mathrm{NaCl}$ ) of ten diploid genotypes of banana (Musa spp.) in an experiment conducted under greenhouse conditions, verified that there was a reduction in the net assimilation rate in all genotypes studied.

Irrigation using water with increasing levels of salinity caused a significant reduction in plant dry mass, corresponding to $14.43 \%$ per unit increase in ECw. The regression equation (Figure 3B) showed that the greatest effect was obtained in plants subjected to the highest level of ECw $\left(3.6 \mathrm{dS} \mathrm{m}^{-1}\right)$, which had a reduction in TDM of $2.93 \mathrm{~g} \mathrm{plant}^{-1}(49.02 \%)$, when compared to those under $0.4 \mathrm{dS} \mathrm{m}^{-1}$. The reduction in biomass accumulation by cashew plants may be related to the high metabolic energy cost imposed by the salt stress for the synthesis of organic solutes for osmoregulation and/or protection of macromolecules, the maintenance of membrane integrity and the regulation of ion transport and distribution in various organs and within cells (Willadino et al., 2011).

Comparing the TDM obtained at the salinity level of $3.6 \mathrm{dS} \mathrm{m} \mathrm{m}^{-1}$ to that achieved under the lowest salinity level $\left(0.4 \mathrm{dS} \mathrm{m}^{-1}\right)$, there were relative reductions in TDM of 48.48, 61.05 and 33.21\%, respectively, in the clones Faga 11, Embrapa 51 and CCP 76 (results not presented). Considering the relative reduction ranges of salt tolerance established by Richards (1954), the clones can be classified as follows: Faga 11 - moderately sensitive (40-60\%); Embrapa 51 - Sensitive (>60\%) and CCP - moderately tolerant (20-40\%).

The succulence in leaf tissues increased linearly with the use of saline water in irrigation and, according to the regression equation (Figure 4A), there was a 32.67 fold increase in the SUC data of cashew plants irrigated with $3.6 \mathrm{dS} \mathrm{m}^{-1}$ water compared to those of plants subjected to $0.4 \mathrm{dS} \mathrm{m}^{-1}$, equivalent to an increase of $0.0931 \mathrm{~g} \mathrm{H}_{2} \mathrm{O} \mathrm{\textrm {cm } ^ { 2 }}$. The increase in the
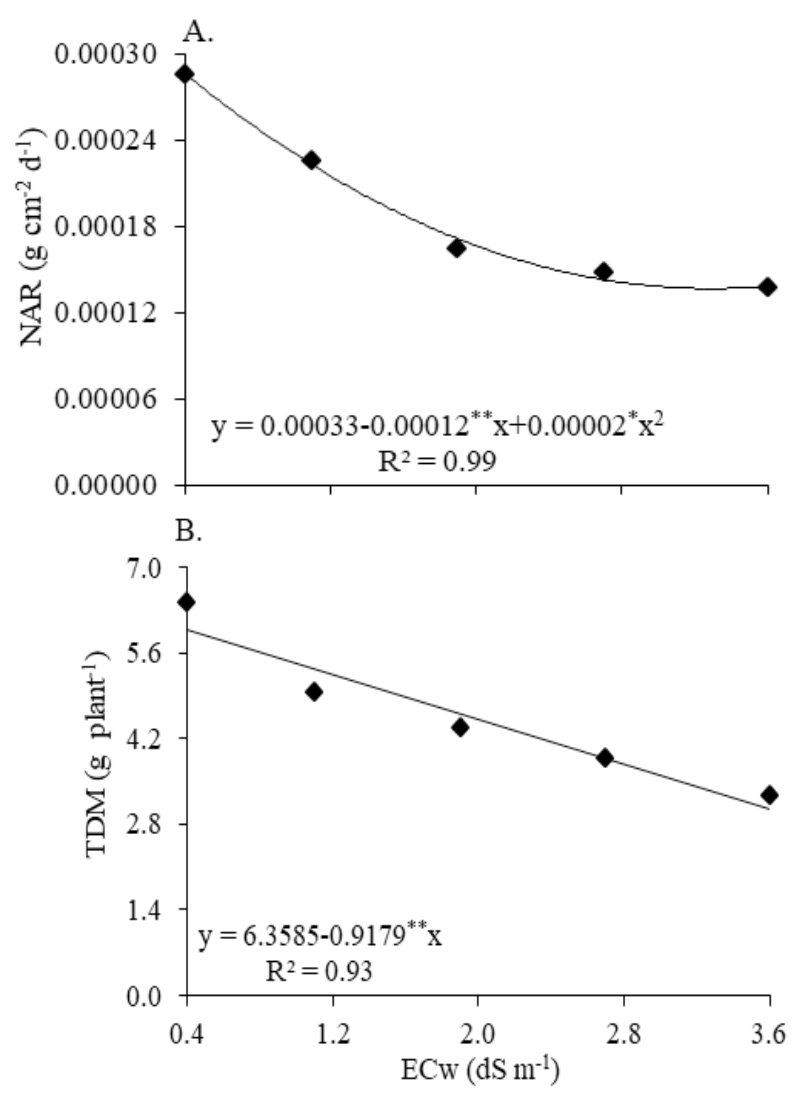

*, ** - Significant at $\mathrm{p} \leq 0.05$ and $\mathrm{p} \leq 0.01$ by F test, respectively

Figure 3. Net assimilation rate - NAR (A), total dry mass TDM (B) of precocious dwarf cashew clones irrigated with saline water $(\mathrm{ECw})$, at 75 days after sowing

succulence of leaf tissues can be highlighted as a mechanism of tolerance and has anatomical and physiological implications in plants cultivated under irrigation with saline waters, because SUC enables the regulation of salt concentration in leaf tissues and directly depends on the absorption, transport and accumulation of ions in tissues, which may contribute to reducing the effect of salts on plants (Trindade et al., 2006). However, despite this increase in SUC with the increase in salinity levels, there was a marked reduction in the synthesis of chlorophyll $\mathrm{a}$ and $\mathrm{b}$ (Figures $1 \mathrm{~A}$ and $\mathrm{B}$ ), growth (Figures 2A, $\mathrm{B}$ and $\mathrm{C}$ ) and quality of cashew seedlings (Figure 5).

According to the result of the means comparison test (Figure 4B), there was a significant effect of cashew clones, and the leaf succulence of CCP 76 was statistically higher than those of the other clones studied (Faga 11 and Embrapa 51). However, when clones Faga 11 and Embrapa 51 were compared, there was no significant difference between them. It is also possible to observe (Figure 4B) that the SUC of CCP 76 was 0.0398 and $0.0662 \mathrm{~g} \mathrm{H}_{2} \mathrm{O} \mathrm{cm}^{2}$ higher than the values of the clones Embrapa 51 and Faga 11, respectively. Thus, the increase in SUC obtained in CCP 76 compared to the other clones can be characterized as greater thickening of the mesophyll cell wall, resulting from the anatomical changes obtained in glycophyte plants under salt stress conditions. This may be related to the increase in the volume of spongy mesophyll cells to the detriment of the volume of the palisade parenchyma cells (Costa et al., 2003). Despite the increase in SUC, CCP 76 was the clone with the lowest DQI (Figure 5). 


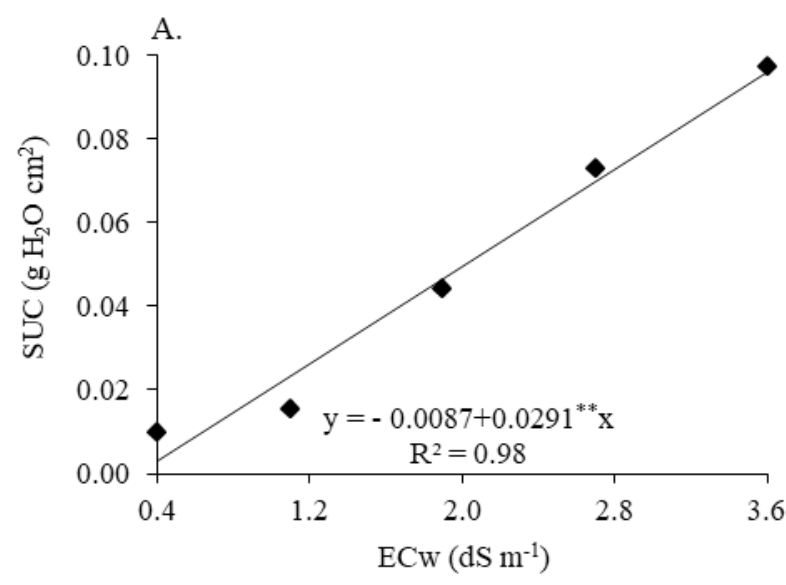

B.

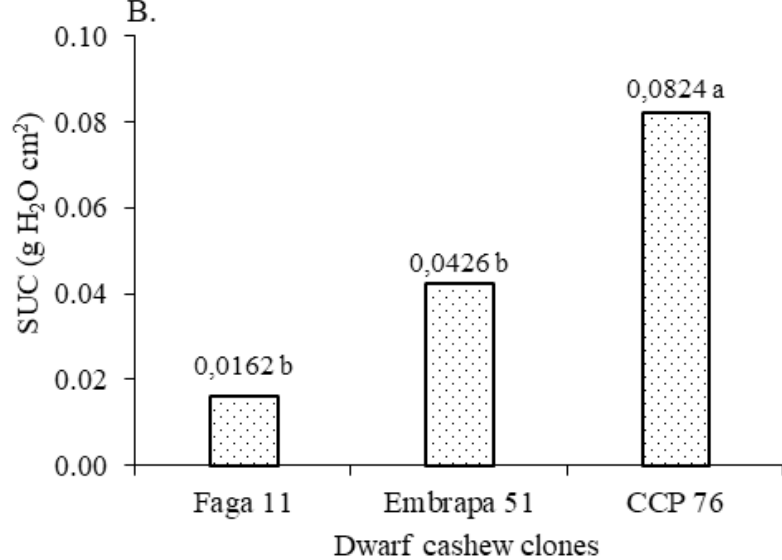

** - Significant at $\mathrm{p} \leq 0.01$ by F test; Means followed by the same letter do not differ at $\mathrm{p} \leq 0.05$ by Tukey test

Figure 4. Leaf succulence - SUC of precocious dwarf cashew as a function of irrigation with saline water (ECw) (A) and clones (B), at 75 days after sowing

DQI was also influenced by the interaction between factors (SL $x \mathrm{CL}$ ). According to the regression equations (Figure 5), the DQI values of the clones Faga 11 and Embrapa 51 decreased linearly with the increase in water salinity. There were reductions of 19.03 and $22.12 \%$ per unit increase in $\mathrm{ECw}$ in the DQI of Faga 11 and Embrapa 51, respectively. In relative terms, the reductions in DQI were equal to 1.48 and 1.75 in the clones Faga 11 and Embrapa 51, respectively. Regarding

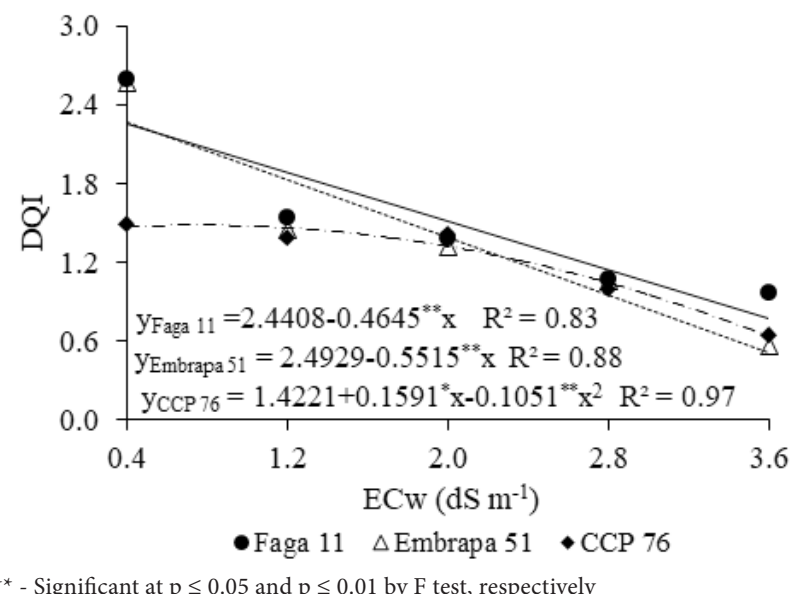

Figure 5. Dickson Quality Index - DQI of precocious dwarf cashew clones as a function of the interaction between irrigation water salinity levels and precocious dwarf cashew clones, at 75 days after sowing
CCP 76, the equation (Figure 5) showed that the data were described by a quadratic model, and the maximum estimated value of 1.482 was obtained when plants were irrigated with $0.8 \mathrm{dS} \mathrm{m}^{-1}$ water. In a comparison of the three clones studied (Faga 11, Embrapa 51 and CCP 76), it was observed that Faga 11, Embrapa 51 and CCP 76 reached maximum DQI values of 2.25, 2.26 and 1.46, respectively. The DQI is an important morphological characteristic used to determine the quality and rusticity of seedlings, as it expresses the capacity for growth and balance in biomass distribution under stress conditions (Oliveira et al., 2013). In this context, it is observed in the present study that even plants irrigated using water with the highest level of salinity $\left(3.6 \mathrm{dS} \mathrm{m}^{-1}\right)$ showed acceptable DQI, since seedlings with DQI greater than 0.2 are considered of good quality (Dickson et al., 1960).

\section{Conclusions}

1. The use of saline waters, with electrical conductivity greater than $0.4 \mathrm{dS} \mathrm{m}^{-1}$, inhibits chlorophyll synthesis and growth, but leads to cashew seedlings with Dickson quality index higher than acceptable limit.

2. Based on the relative reduction of total dry mass, the clones Faga 11, Embrapa 51 and CCP 76, at the seedling formation stage, are classified as moderately sensitive, sensitive and moderately tolerant to water salinity of $3.6 \mathrm{dS} \mathrm{m}^{-1}$, respectively.

3. There is interaction between water salinity levels and precocious dwarf cashew clones for chlorophyll a, chlorophyll $\mathrm{b}$ and Dickson Quality Index, at 75 days after sowing.

\section{Literature Cited}

Araújo, L. F. de; Lima, R. E. M.; Costa, L. de O. da; Silveira, E. M. de C.; Bezerra, M. A. Alocação de íons e crescimento de plantas de cajueiro anão-precoce irrigadas com água salina no campo. Revista Brasileira de Engenharia Agrícola e Ambiental, v.18, p.S34-S38, 2014. https://doi.org/10.1590/1807-1929/agriambi. v18nsupps34-s38

Arnon, D. I. Copper enzymes in isolated cloroplasts: Polyphenoloxidases in Beta vulgaris. Plant Physiology, v.24, p.1-15, 1949. https://doi. org/10.1104/pp.24.1.1

Benincasa, M. M. P. Análise de crescimento de plantas, noções básicas. 2.ed. Jaboticabal: FUNEP, 2003. 41p.

Bezerra, I. L.; Nobre, R. G.; Gurgel, M. T.; Gheyi, H. R.; Fernandes, P. D. Índices fisiológicos e de crescimento de porta-enxertos de cajueiro anão-precoce sob estresse salino. Espacios, v.38, p.4-10, 2017.

Carneiro, P. T.; Cavalcanti, M. L. F.; Brito, M. E. B.; Gomes, A. H. S.; Fernandes, P. D.; Gheyi, H. R. Sensibilidade do cajueiro anãoprecoce ao estresse salino na pré-floração. Revista Brasileira de Ciências Agrárias, v.2, p.150-155, 2007. https://doi.org/10.5039/ agraria.v2i2a1894

Cavalcante, L. F.; Dias, T. J.; Nascimento, R.; Freire, J. L. de O. Clorofila e carotenoides em maracujazeiro-amarelo irrigado com águas salinas no solo com biofertilizante bovino. Revista Brasileira de Fruticultura, v.especial, p.699-705, 2011. https://doi.org/10.1590/ S0100-29452011000500098 
Costa, P. H. A.; Silva, J. V.; Bezerra, M. A.; Gomes Filho, J. E.; Prisco, J. T.; Gomes Filho, E. Crescimento e níveis de solutos orgânicos e inorgânicos em cultivares de Vigna unguiculata submetidos à salinidade. Brazilian Journal of Botany, v.26, p.289-297, 2003. https://doi.org/10.1590/S0100-84042003000300002

Dalchiavon, F. C.; Neves, G.; Haga, K. I. Efeito de stresse salino em sementes de Phaseolus vulgaris. Revista de Ciências Agrárias, v.39, p.404-412, 2016. https://doi.org/10.19084/RCA15161

Dickson, A.; Leaf, A. L.; Hosner, J. F. Quality appraisal of white spruce and white pine seedling stock in nurseries. The Forest Chronicle, v.36, p.10-13, 1960. https://doi.org/10.5558/tfc36010-1

Diniz, B. L. M. T.; Cavalcante, L. F.; Mesquita, F. de O.; Lima Neto, A. J. de; Nunes, J. C.; Diniz Neto, M. A. Crescimento inicial e consumo hídrico de nim submetido ao estresse salino e biofertilizante bovino. Revista Brasileira de Ciências Agrárias, v.8, p.470-475, 2013. https://doi.org/10.5039/agraria.v8i3a2613

Falk, J.; Munné-Bosch, S. Tocochromanol functíons in plants: Antioxidation and beyond. Journal of Experimental Botany, v.61, p.1549-1566, 2010. https://doi.org/10.1093/jxb/erq030

Ferreira, D. F. Sisvar: A guide for its bootstrap procedures in multiple comparisons. Ciência e Agrotecnologia, v.38, p.109-112, 2014. https://doi.org/10.1590/S1413-70542014000200001

Freire, J. L. de O.; Cavalcante, L. F.; Nascimento, R. do; Rebequi, A. M. Teores de clorofila e composição mineral foliar do maracujazeiro irrigado com águas salinas e biofertilizante. Revista de Ciências Agrárias, v.36, p.57-70, 2013.

Freitas, M. A. C.; Amorim, A. V.; Bezerra, A. M. E.; Pereira, M. S.; Bessa, M. C.; Nogueira Filho, F. P.; Lacerda, C. F. Crescimento e tolerância à salinidade em três espécies medicinais do gênero Plectranthus expostas a diferentes níveis de radiação. Revista Brasileira de Plantas Medicinais, v.16, p.839-849, 2014. https:// doi.org/10.1590/1983-084X/12_152

Gomes, K. R.; Amorim, A. V.; Ferreira, F. J.; Andrade Filho, F. L.; Lacerda, C. F.; Gomes-Filho, E. Respostas de crescimento e fisiologia do milho submetido a estresse salino com diferentes espaçamentos de cultivo. Revista Brasileira de Engenharia Agrícola e Ambiental, v.15, p.365-370, 2011. https://doi. org/10.1590/S1415-43662011000400006

Khalid, A.; Silva, J. A. T. Yield, of essential oil and pigment content of Calendula officinalis L. flower heads cultivated under salt stress conditions. Scientia Horticulturae, v.126, p.297-305, 2010. https:// doi.org/10.1016/j.scienta.2010.07.023

Lima, G. S. de; Dias, A. S.; Souza, L. de P.; Sá, F. V. da S.; Gheyi, H. R.; Soares, L. A. dos A. Effects of saline water and potassium fertilization on photosynthetic pigments, growth and production of West Indian cherry. Revista Ambiente \& Água, v.13, p.1-12, 2018. https://doi.org/10.4136/ambi-agua.2164

Mantovani, A. A method to improve leaf succulence quantification. Brazilian Archives of Biology and Technology, v.42, p.9-14, 1999. https://doi.org/10.1590/S1516-89131999000100002

Munns, R.; Tester, M. Mechanisms of salinity tolerance. Annual Reviews of Plant Biology, v.59, p.651-681, 2008. https://doi. org/10.1146/annurev.arplant.59.032607.092911
Novais, R. F.; Neves, J. C. L.; Barros, N. F. Ensaio em ambiente controlado. In: Oliveira, A. J. Métodos de pesquisa em fertilidade do solo. Brasília: Embrapa Informação Tecnológica 1991. p.189253.

Oliveira, F. T.; Hafle, O. M.; Mendonça, V.; Moreira, J. N.; Pereira Júnior, E. B. Fontes orgânicas e volumes de recipiente no crescimento inicial de porta-enxertos de goiabeira. Revista Verde de Agroecologia e Desenvolvimento Sustentável, v.7, p. 97-103, 2013.

Richards, L. A. Diagnosis and improvement of saline and alkali soils. Washington: U. S. Department of Agriculture, 1954. 160p. Agriculture Handbook, 60

Silva, E. M. da; Nobre, R. G.; Souza, L. de P.; Pinheiro, F. W. A.; Lima, G. S. de; Gheyi, H. R.; Almeida, L. L. de S. Physiology of 'Paluma' guava under irrigation with saline water and nitrogen fertilization. Semina: Ciências Agrárias, v.38, p.623-634, 2017. https://doi. org/10.5433/1679-0359.2017v38n2p623

Sousa, A. B. O. de; Bezerra, M. A.; Farias, F. C. Germinação e desenvolvimento inicial de clones de cajueiro comum sob irrigação com água salina. Revista Brasileira de Engenharia Agrícola e Ambiental, v.15, p.390-394, 2011. https://doi. org/10.1590/S1415-43662011000400010

Sousa Junior, G. de S. E; Morais, M. B. de; Camara, T. R.; Willadino, L. Crescimento de genótipos diplóides de bananeira submetidos ao estresse salino. Revista Brasileira de Engenharia Agrícola e Ambiental, v.16, p.1145-1151, 2012. https://doi.org/10.1590/ S1415-43662012001100001

Souza, L. de P.; Nobre, R. G.; Gheyi, H. R.; Bonifácio, B. F.; Lima, G. S. de; Fatima, R. T. de; Souza, C. M. A. de; Oliveira, S. G. de. Morphophysiology of 'Faga 11' cashew rootstock under saline water irrigation and exogenous proline application. Journal of Agricultural Science, v.10, p.402-411, 2018. https://doi. org/10.5539/jas.v10n9p402

Suassuna, C. F.; Ferreira, N. M.; Sá, F. V. S da; Bertino, A. M. P. de; Mesquita, E. F.; Paiva, E. P.; Bertino, A. M. P. Substratos e ambientes para produção de mudas de cajueiro anão precoce. Agrarian, v.9, p.197-209, 2016.

Teixeira, P. C.; Donagemma, G. K.; Fontana, A.; Teixeira, W. G. (org.). Manual de métodos de análise de solo. 3. ed. Brasília, DF: Embrapa, 2017. 573 p.

Trindade, A. R.; Lacerda, C. F. de; Gomes Filho, E.; Prisco, J. T.; Bezerra, M. A. Influência do acúmulo e distribuição de íons sobre a aclimatação de plantas de sorgo e feijão-de-corda, ao estresse salino. Revista Brasileira de Engenharia Agrícola e Ambiental, v.10, p.804-810, 2006. https://doi.org/10.1590/S141543662006000400004

Willadino, L.; Gomes, E. W. F.; Silva, Ê. F. de F.; Martins, L. S. S.; Camara, T. R. Efeito do estresse salino em genótipos tetraploides de bananeira. Revista Brasileira de Engenharia Agrícola e Ambiental, v.15, p.53-59, 2011. https://doi.org/10.1590/S141543662011000100008 